\title{
Gender Expertise in Global Governance: Contesting the Boundaries of a Field ${ }^{1}$
}

Rahel Kunz

University of Lausanne

Rahel.Kunz@unil.ch

\author{
Elisabeth Prügl
}

Graduate Institute, Geneva

elisabeth.pruegl@graduateinstitute.ch

Hayley Thompson

Rutgers University

hayley.thompson@graduateinstitute.ch

This is an Accepted Manuscript of an article published by Bristol University Press in European Journal of Politics and Gender 2, 1 (February 2019) : 23-40. Available online at https://doi.org/ 10.1332/251510819X15471289106112

\footnotetext{
${ }^{1}$ Research for this article was carried out in the context of a collaborative research project on gender experts and gender expertise. We are grateful for stimulating discussions with our project colleagues Françoise Grange and Christine Verschuur at the Graduate Institute in Geneva. Funding by the Swiss National Science Foundation is gratefully acknowledged [PA00P1_145335 and 100017_143174]. We also would like to thank Özlem Altan-Olcay, whose close reading of an earlier draft of this article alerted us to the fact that we were all three talking about boundary drawing practices. Special thanks go to all our survey and interview respondents for taking time and sharing their experience with us.
} 


\begin{abstract}
This article conceptualizes gender expertise in global governance as a transnational field structured by cleavages and struggles. We situate the phenomenon within the literature on gender mainstreaming and transnational expertise and make the case for a new way to theorise gender expertise. We propose two main theoretical shifts: a depersonalization in order to understand expertise as a field rather than experts as individuals or a group of people; and a reconceptualisation of expertise from a depoliticized body of knowledge divorced from its knowers towards expertise as a performative and intrinsically political practice. Drawing on qualitative data we identify practices of boundary drawing and boundary erasing to provide an understanding of the contours and key dynamics of this field. These include struggles over the boundary between gender expertise and feminism; between different types of experts; and over framings between experts in headquarters and "the field." The analysis of these contestations surrounding gender expertise interventions allows us to interrogate the power politics of expert discourses.
\end{abstract}


The strategy of gender mainstreaming has led to the establishment of gender expertise in global governance. There are today many professionals working in governments, international bureaucracies, and non-governmental organizations who are tasked to advance the goal of gender equality. They share specialized knowledge about what gender is, how gender inequality is perpetuated, and what is necessary to change this. They have also devised various techniques of mainstreaming gender into all areas of global governance, including development, security, agriculture, human rights and migration. While there is a sizeable literature exploring the experiences of those working on gender issues in international governance institutions, much less is known about gender expertise as a social and political phenomenon.

In this article we explore this phenomenon through a practice approach. We suggest that gender expertise in international governance constitutes a transnational social field established through the practices of gender experts connected in border-crossing networks. Theorising gender expertise as a transnational field allows us to make visible aspects of the phenomenon that have not received sufficient attention in the existing feminist literature on gender mainstreaming. It allows us to shift the focus from the struggles and co-optations of individual feminists inside organizations to political practices in the social field in which they participate. It also allows us to question the idea that expertise depoliticizes and to bring to light the complexity of political struggles suffusing the practice of expertise. In doing so, we hope to achieve a rethinking of the way feminist scholarship approaches both expertise and feminism: feminism itself is implicated in a politics of expertise while expertise includes struggles over feminism. It is the specific contours of these mutual imbrications that need to become the focus of research.

With Anna Leander, we understand a field as an "an organizing logic around a 'stake at stake', visible through its effects and dominating everyone concerned by the stake at stake whether or not they are conscious of participating in the field and/or actively engaged in the struggle for defining that stake" (Leander, 2010, p. 4). This field is structured; i.e. it is functionally differentiated (for example between those working on 
mainstreaming processes and those integrating gender in particular issue areas) and there are hierarchies and hegemonies based on social and symbolic capital, including that derived from different kinds of knowledge. Importantly, the field is bounded and boundary-drawing practices are central to establishing and maintaining the field. Through such practices gender expertise differentiates itself from other fields and protects itself from what it considers extraneous. We postulate that the structure and boundaries of the field are constantly contested, and that ongoing negotiations of boundaries involve a range of power relations. We illustrate the character of three types of particularly salient boundary contestations, drawing on data collected in the context of a collaborative research project on gender experts and gender expertise (2012 - 2015). First, we explore the boundaries gender experts seek to draw or erase between gender expertise and feminist politics, second we examine contestations over scientific epistemologies and authority, and third we make visible struggles over the (post)colonial politics of location surrounding gender expertise.

The purpose of our research project was to map the transnational field established by gender experts, examine the content of their expertise and its translations in different contexts. It consisted of three subprojects, one exploring expertise reflected in documents, a second mapping the field by means of an online survey and interviews, and a third exploring translations of expertise in several local contexts through interviews and ethnographic methods. We started from the assumption that gender expertise is organized along issue areas and thus sampled across institutional and state boundaries. In this article we draw in particular on findings from our survey and interviews. The survey was addressed to 600 individuals we identified as working on gender for international organizations or international non-governmental organizations, whether as employees or contractors, in headquarters or field offices. We identified these individuals by approaching relevant organizations and scouring their websites. We got responses from 118 individuals, a response rate of about 20 per cent. $^{2}$ In addition to the survey we carried out a total of about 160 semi-structured in-depth

2 Detailed results of the survey are published in Thompson and Prügl, 2015. 
interviews with individuals engaged in gender-related work in international intergovernmental and non-governmental organizations (IOs and INGOs) in Washington, Geneva, New York, and Rome, and in international and local governmental or non-governmental institutions in Monrovia and Kathmandu. Liberia and Nepal were selected for fieldwork because they are "post-conflict" countries and feature longstanding international development and peacebuilding interventions with large gender mainstreaming machineries that are firmly embedded in the transnational field of gender expertise. Interviews were transcribed, coded and analysed using NVivo software. ${ }^{3}$

In what follows, we first embed our study in the relevant literature and expand on our theoretical approach to the study of gender expertise. We then provide an analysis of the main cleavages and boundary contestations in the field of gender expertise allowing us to highlight politics and power relations. We focus in particular on (a) contestations seeking to draw a line between feminism as a movement and gender expertise; (b) the negotiation of epistemic boundaries between feminist expertise and other types of expertise; and (c) contestations over exclusionary hierarchies and hegemonies in the field along (post-)colonial differences of location.

\section{Reconceptualising the Study of Gender Experts and Expertise}

A growing literature chronicles the ambivalent position of those working on gender mainstreaming in government and international bureaucracies and makes visible the "discursive virtuosity" of gender equality workers in negotiating resistances and tensions in the context of neoliberal and technocratic work environments and governmental logics (Brunila 2013; Ross 2018; Bustelo et al., 2016; Ferguson 2015; Eyben and Turquet 2013; Hertzog 2011). This literature contradicts critiques of the work of gender experts as depoliticising and a sell-out of feminism and implicitly questions the opposition between politics and expertise that underlies such critique. ${ }^{4}$ This is true not

$3 \quad$ REF taken out for anonymity reasons.

$4 \quad$ For a more extensive review of this literature see the Introduction to this special issue. 
only for literature on gender mainstreaming, but also for literature on expertise more broadly. For example an influential strand of International Relations (IR) literature suggests that expertise gives legitimacy to epistemic communities, policy networks, and the policies of international organizations precisely because it can claim to stand above politics (Haas, 1992; Haas and Haas, 2002; Boswell, 2008; Littoz-Monnet, 2017). In contrast, those taking a practice approach have shown that expertise walks a fine line between science and politics and occupies a boundary position, "translating between different domains and sometimes even policing the boundary between them" (Berling and Bueger 2015, p. 9). They problematize the way in which experts compete for authority in international governance and the way they organize in transnational networks to order to gain control of issues (Sending 2015; Seabrooke and Henriksen 2017). Our approach is informed by these reconceptualizations of expertise, which allow us to postulate that politics and expertise are linked. Moreover, they train our focus on the "fuzzy zones of contact and overlap," and invite us to conceptualise gender expertise interventions as contestations in "interstitional domains" (Eyal and Buchholz, 2010a, pp. 120, 132). We also build on feminist literature on expertise in a Foucaultian vein that similarly approaches expertise as political. This literature has examined the politics of gender expertise for example in identity constructions and neoliberal governmentality, highlighting the power effects of various identifications of women and exploring the way they are inserted in logics of the market and security (Prügl, 2016; Kunz, 2016, 2017; Griffin, 2009; Shepherd, 2017). Thus we conceptualize expertise as thoroughly political, a field rent by struggles and contestations over authority and boundaries, exclusions and hierarchies.

A Bourdieusian approach helps us conceptualize the way in which expert authority is produced through contestation, competition for symbolic capital, and the establishment of boundaries (Bourdieu, 1988, 1999). We adopt from Bourdieu the notion of social fields, which has opened up the analytical terrain in International Relations to make visible social formations transgressing boundaries of states and formal institutions, such as elite and expert networks (Dezalay and Garth, 2011; Adler-Nissen, 2014; Sending, 
2015). ${ }^{5}$ We propose a theorisation of expertise that includes a double shift. First, we shift from the focus in the gender mainstreaming literature on experts as particular types or groups of people to the construction of expertise within a social field that constitutes what gender experts are, how they work, and what is considered as expert knowledge. We combine this with insights from recent studies that emphasise the fragility of expertise resulting in "governance failures" and recognize the fact that social sciences expertise is built on contested grounds (Best, 2014). This move depersonalises the object of analysis and highlights instead the constitution and functioning of the field together with the "intellectual spaces, their sociocultural properties, and the multiple positions and claims that they encompass" (Eyal and Buchholz, 2010b, p. 124). The second shift is from the focus on expertise as a body of knowledge divorced from its knowers, as in some Foucaultian treatments of gender mainstreaming, to expertise as performative. We thus approach expertise as conduct that constitutes the field and is constituted by the field; this involves boundary-negotiating practices and the construction of authority via the accumulation of symbolic capital. The approach resonates with insights from the sociology of the professions, which acknowledges that professionals are often aware of their role in solidifying or shaking processes of institutionalization in their day-to-day work (Muzio, Brock, and Suddaby 2013). We also take seriously the insight that the performance of gender expertise cannot be separated from the performance of intersecting identities, in particular gender, race and class (Brady 2018).

These two moves lead us to take as an entry point to our study the various practices of boundary negotiation that constitute the field of gender expertise. Gender experts strategically draw and erase boundaries to get heard and to establish their authority. While in some contexts, practices of erasing boundaries between gender and other experts allow gender expertise to be established as legitimate, in other contexts, it is the drawing of boundaries that confers authority to gender expertise, for example when experts highlight their training in the North. Focusing on boundary negotiations and the

$5 \quad$ For a comparable effort drawing on neo-Weberian sociology of the professions, see Faulconbridge and Muzio 2011. 
performativity of expertise allows us to explore the structuring of the field in conjunction with the type of knowledge and power effects that are produced in efforts to introduce feminist ideas into global governance.

\section{Contestations and Boundary Struggles}

Our interview data shows vividly that gender experts are positioned on boundaries they continuously have to negotiate. Here, we illustrate three major cleavages and fronts of struggle: a struggle over the boundaries between gender expertise and feminist politics; a struggle for scientific epistemologies and authority at the boundary of gender studies and other forms of expertise; and struggles for recognition and authority between gender expertise from different sites and institutions linked to post-colonial politics. We explore the constitution of the field of gender expertise through boundary drawing, erasing, and negotiating practices.

\section{Gender Expertise and Feminisms}

The field of international gender expertise emerged as a result of feminist movement activism and lobbying of states in international institutions. Given this backdrop, the field continues to have to negotiate its relationship to feminisms. Many gender experts do not self-identify as feminists or do so only in private. Indeed, our survey found that over $\mathbf{4 0}$ per cent rejected the label feminist to describe themselves. However, most of our interviewees had strong and often contradictory opinions about feminism. On the one hand were those who wished to solidify the boundaries of the field against feminists and feminisms; they argued that feminism was irrelevant, too extreme, or at least unhelpful for the work of gender experts. On the other hand were those who sought to include feminism in the field, claiming that only a real and open commitment to advocating for women's rights makes a good gender expert and that gender experts should answer to the demands of feminist movements.

Among those who sought to establish feminism as different from gender expertise, one argument was to suggest that feminism was irrelevant to their work, that it pertained to 
one's personal and private identity. In the words of one expert at the World Bank: "For me, identifying as a feminist is almost as declaring yourself catholic or not. It has to do with a whole bunch of beliefs and you can be one or other" (Interview World Bank, Washington, 2015). But ultimately, she suggested, it does not matter whether somebody working on gender is a feminist. Feminism for her constituted an identity, not a body of knowledge and therefore was irrelevant to successfully performing gender expertise.

A related argument was that feminism was a form of politics, necessary at one time but now outdated. In the view of a gender expert working in the UN's Food and Agriculture Organization:

Feminism was the origin of the idea of equality, and at the time it was needed. As always you need some strong advocates to in the first place bring the issue on the table. And, then you have to go down and elaborate, conceptualize ... gender equality for me is not feminism. You start with wanting to obtain too much to be able to get something. So, in that sense, I think feminism is necessary at a certain point to bring the issue; again, historically. (Interview FAO, Rome, 2012)

In both of these quotes feminism is purged from the field of gender expertise. For the second interviewee this is necessary so that feminism does not inhibit the maturation of the field. The emphasis is on renegotiating the initial content of the field so that it becomes something more logically developed and serious, on getting away from the "catholic irrationality" of feminist beliefs so that one can focus on "the issue." In other words, expertise here means knowledge freed from movement politics, drawing a boundary that supposedly excludes the political.

But we also found arguments that sought to purge feminism from the field because it was thought to inhibit the agenda that gender experts were hired to advance. There is in this argument an implicit acknowledgment that expertise is political-but in the wrong 
way. One such argument was based on negative and stereotypical understandings of feminism. We encountered a surprising number of references to bra-burning feminists and efforts to distance oneself from this icon, as in "We're not just like annoying, you know, bra-burning feminists" (Interview UN Women Peace and Conflict, New York, 2013). This gender expert clearly thought this radical definition of feminism was wrong; but others embraced it and as a result rejected feminism altogether. In the latter case, feminism often was associated with "hating men," and/or was perceived as violent and extreme, and therefore not welcome inside the boundaries of the field of proper gender expertise. For example, asked about the meaning of feminism, a gender expert working for UN Women in Liberia replied:

I know someone who said she was a feminist. It was more like she hates men. I was trying to think, is this what it's supposed to be? ... It was more like an extremist. Where do you draw the line? ... if you start to hate the opposite sex, it's really a bit extreme because ... you need him (man) as an example to change the mindset of other men. (Interview UN Women, Monrovia, 2013)

From the perspective of this expert feminism's radicalism was problematic, not because it polluted expertise, but because it threatened the reformative work. Feminism was understood as excluding or even "hating" men, which was detrimental to the aim of convincing and including men into gender mainstreaming activities.

Of course, understandings of feminism as unreasonable and extreme permeate international cultures and these understandings are part of an environment that gender experts need to negotiate in their work. Thus, even experts who self-identified as feminists were sometimes cautious about using the term. When asked whether most of her colleagues would call themselves feminists, one expert from the World Bank's gender unit replied:

They probably wouldn't do it in public because, you know, it probably wouldn't help you and if anything, it would hurt you. ... I wouldn't go into a Bank meeting and call myself a 
feminist because I think the kind of implicit message is that if you're not a feminist then somehow you don't believe in gender equality and you're a worse person morally and ethically. Maybe you think that, but you don't want to say it because you need to bring people along. You're in a large organization and I think there's a premium on affinity rather than saying that you're different and somehow, kind of better and implicitly better than others. (Interview World Bank, Washington, 2014)One of our interviewees, who called herself "a real feminist" went so far as to suggest a kind of closeted and undercover existence: "because if you are a feminist it means that you are a troublemaker, you are against the men. ... And people ... will be extremely resistant to any ideas you will be able to propose. So ... one of the challenges is to ... be able to keep a low profile and not expose yourself as a feminist" (Interview UN Secretariat, Geneva, 2012).

Thus gender experts-both feminists and non-feminists-are engaged in erecting boundaries to keep their work safe from feminism. They may either have a narrow definition of feminism as profoundly different from expertise, disagree with the radical knowledge of feminism, feel threatened by stereotypical understandings of feminism, or be wary of appearing as different in organizations that value affinity. In all instances they participate in drawing a specific boundary around gender expertise that establishes it as a body of knowledge free of politics.

But not all of our experts agreed that feminism was irrelevant, extreme, or unhelpful. They may have agree that it is necessary to be pragmatic, but they also recognized various forms of feminist knowledge as invaluable and/or necessary to gender expertise. Gender experts adopting this approach sometimes openly self-identified as feminists or said that they were working towards becoming "real feminists" (Interview UN Women, Monrovia, 2013). They suggested that a real and open commitment to feminist values and objectives is necessary for doing good work on gender issues. Rather than drawing boundaries, they sought to erase boundaries. One respondent, a gender expert from West Africa with many years of experience working both "in the 
field" as well as in headquarters in New York, replied when asked whether she would call herself a feminist:

I have actually told people in training that I am a feminist and of course they have the same response, so, so, so ... And l'm like, ok let's define feminism. Sometimes there is real misconception about what feminism is, and I think we need to also put that on the table and have a discussion about it. (Skype interview UN Women, 2013)

The gender expert in the UN Secretariat cited above pointed out that her feminism helps her remember what the larger mission is-she clearly sees the feminist movement as her audience and feels accountable to it:

I think ... if you are a feminist and you have a feminist perspective you will be deconstructive all the time, right? You understand what it means to work within a patriarchal organization ... My concern, if you have a gender adviser who is not a feminist is that that woman is going to probably not challenge the system enough. She will be playing you know safe ... being maybe controlled or guided by the top management trying to fit within the system. I am not saying that I am not trying to fit because remember when I said at the beginning to be a good gender adviser you need to have too diplomatic skills, political skills, but you need to be extremely clear about your own approach. (Interview UN Secretariat, Geneva, 2012)

Others called for diversifying the meanings of feminism. They also recalled the plurality of feminist histories situated within various cultural and historical contexts and emphasised a focus on local women's movements. Thus, for example, one male respondent from an NGO in Nepal gave the following definition of feminism:

A feminist would actually be someone who goes through all those things that people go through. ... Sometimes I feel that I'm a feminist as well because I 
actually understand the woman inside me. That is a discussion we always have in our team when we talk about masculinity we say that a man has a woman inside as well, and I acknowledge that. ... In that way, a feminist is someone who has this human approach ... and feels equally fit to actually advocate for their rights, rather than people born with a silver spoon in their mouth, and they have got a Harvard degree or big degrees out there ... A feminist would be a local leader for me, a woman, a man, a boy ... who actually understands the human sentiments and cultural norms associated with their problem. (Interview NGO, Kathmandu, 2015)

Feminism thus splits the opinions of the gender experts we interviewed. Whereas for some it constitutes a threat either to their professional credibility or to the advancement of movement goals, for others, it was a rich resource. It provides an analytical tool to make global connections, a methodology to retain awareness of power relations in patriarchal institutions, and a way of relating to others and being a leader. The section makes clear that gender expertise is not simply de-politicized knowledge emptied of feminist goals. There is no doubt a tendency in this transnational field to purify it from the taint of association with a political movement. Yet, this tendency is contested, the value of feminisms recognized and the meaning of feminism itself under negotiation. The boundary struggles over the role of feminism thus amount not only to a struggle over the soul of gender expertise but question at the same time the image of expertise as technical and non-political.

\section{Gender Expertise and Epistemic Politics}

A second site of contestation involves the boundary between critical gender expertise on the one hand and practical and scientific knowledge on the other. According to literature on the sociology of the professions, expert authority derives from two sources-from the association with an academic discipline that provides a theoretical grounding, and from the distinctive techniques that allow experts to make theoretical knowledge practical (Abbott, 1988). But, for the most part, gender experts do not share a common academic background. According to our survey, only 10 per cent graduated 
with a university degree in gender studies, (making it, however, the second-largest category, behind international law at 11 per cent). About 40 per cent had never taken a class in gender studies or done research on gender issues. Moreover, following the logic of mainstreaming, gender experts typically straddled two or more areas of specialization in their work: Only around 15 per cent indicated a primary focus on gender; most worked on gender in addition to other areas such as agricultural economics or human rights. Not surprisingly, there is therefore contestation among gender experts regarding which types of knowledge and methodologies to consider authoritative, and what it means to be practical; and that contestation involves drawing boundaries to other disciplines_often gender studies_but also taking advantage of the authority conveyed by existing disciplines and erasing boundaries vis-à-vis them.

As a young and strongly contested field, gender expertise often has struggled to show its practical value. In the words of one of our interviewees:

For better or worse, rather than having a real profession, a lot of gender advisers are people who are just fluent in the language of sex and gender .... But when it comes to offering practical solutions, when a program manager is like okay, sure, I understand all that, now tell me how to address women, you know, women's needs, roles in an infrastructure project, they're not able to do that. And thenthat's obviously a mass generalization that often doesn't help the challenges gender advisors face-but there's in general, there's an assumptions that gender advisors are all kind of useless and don't really bring much to the table. (Interview International Committee of the Red Cross, Geneva, 2012)

The problem seems to be "the language of sex and gender," which is judged as unpractical because it has little to say about solutions. Simply questioning existing gender dynamics and exclusions is considered as not useful because it does not tell a practitioner what to do. Indeed, a critical approach can become a liability in 
governmental settings, as expressed in this quote from a gender expert at the World Bank:

The only thing they would say, well, there should be more gender. Well, I mean, yeah, then what? Tell us what may be more constructive. ... I think kind of on the diagnostic side and kind of recognize the differential kind of constraints and opportunities, and part of that is about thinking about solutions, so you are doing this road project, so, what should you be doing on this, .... You can't just criticize. (Interview World Bank, Washington, 2014)

Behind these quotes hides a specific understanding of practicality: knowledge is practical when it is able to provide clear-cut solutions amenable to technical manipulation and intervention. That the demand is made with reference to infrastructure projects in both cases is no coincidence-these projects epitomize solutions on offer in international development expertise. More training in gender studies, a field that emphasizes critical methodologies, would do little to alleviate the problem of practically thus conceived. While questioning fundamental presumptions and silences has profound impact on real-world understandings, it sits uneasily with technocratic solutions. Feminist knowledge and gender studies thus struggle to gain authority in the technocratic contexts of international governance.

Given this, some gender experts look for authority by drawing on other academic fields to inform their professional diagnoses and interventions. They particularly seek to erase boundaries between gender expertise and knowledge that is considered scientific. In the words of one gender consultant, who has worked for a variety of organizations: "People want to hear scientific explanation of why gender is important and how" (Interview UN Secretariat, Geneva, 2012). Scientific knowledge often means quantitative knowledge and the employment of positivist methodologies. This is illustrated particularly well in the case of the World Bank, which has a strong focus on positivist research. Gender experts in the Bank need to know economics: "You need to 
speak the language and you also need to have somebody from that field because it's very easy to say, 'This is soft, this is humanities.' It's all about our equations. ... So it's a little bit more effective to have that person who can combine both" (Interview World Bank, 2014). And in order to be able to do the equations it is necessary to have a particular kind of data. As one expert argued when asked whether there was resistance to considering gender in some areas of the Bank: "resistance is not a matter of issue areas but of not enough data or 'sound proof' that change is necessary" (Interview World Bank, 2015). Some Bank staff recognized the limits of quantitative economics and insisted that "There needs to be qualitative data. You need social scientists. You need anthropologists" (Interview World Bank, 2013), but these voices constituted a minority.

Embedding gender knowledge in particular disciplines conveys authority because of its association with science and numbers. But it also has a pernicious effect: it favours arguments that instrumentalize gender equality for other purposes. This becomes evident in the following quote from an UN Women expert in the area of peace and security. She also diagnosed a lack of good, systematic data, and understood that such data were particularly effective in showing what gender equality is good for: "There is the lack of empirical evidence often that gender equality isn't just good advocacy or good rights-based advocacy and policy, but that it also ensures a good outcome for everyone" (Interview UN Women, New York, 2012). Empirical evidence can show how gender equality has broader, positive effects, how it "ensures a good outcome for everyone"-gender equality itself seems to fade away as a goal. But some gender experts also expressed concern about this tendency, showing reflexivity and a distinctive understanding of the epistemic politics of the field:

I also will use neutral language, or I will also frame something by another issue in order to get more acceptance, and I think there is some utility to that, and there is also some real risk to losing sight of what the point is, to being able to speak the truth about something. I don't know what the best is to be honestly but I think 
that's also why the voice of activism and the voice of society is so absolutely critical and important, because if we don't have that to hold us accountable and also to remind us and to also push things forward in a much more direct way, then those of us who I think get entrenched with institutions and bureaucracies in our desire to do good, sometimes move too far away from the real point. (Interview Geneva Centre for the Democratic Control of the Armed Forces, Geneva, 2014)

Concern for "doing the right thing" and not moving away from the "real point" looms behind the practicality of positivist expertise. Interestingly, in the quote above, the guarantee for doing the right thing seems to be feminism ("activism and the voice of society"), not technical knowledge.

Gender expertise thus scales the boundary between critical and positivist knowledge in an effort to become practical. Experts are aware of the demand for practicality and easily submit to positivist logics promising technical insights and solutions. Yet some also recognize the importance and practicality of critique. Gender expertise again emerges as a profoundly political terrain that enacts epistemological tensions familiar in the social sciences in a quest for practicality.

\section{Gender Expertise and Post-colonial Politics}

A third issue of contestation within the transnational field of gender expertise derives from its embeddedness in post-colonial politics, which shape its boundary-negotiating practices. The post-colonial feminist literature highlights how gender issues have played a key role during colonisation and imperialism (Spivak, 1985; e.g. Chatterjee, 1989; Sinha, 1995; Lugones, 2008; Towns, 2009; Icaza, 2017). Gender and global governance issues continue to be shaped by coloniality, that is "the hidden process of erasure, devaluation, and disavowing of certain human beings, ways of thinking, ways 
of living, and of doing in the world" (Mignolo in Gaztambide-Fernández 2014, 198). Logics of coloniality thus influence the field of gender expertise, which is embedded in geopolitical preoccupations. This section shows that logics of coloniality take various forms in the field of gender expertise, involving a number of boundary drawing and erasing practices. Yet, our interviews also highlight that gender experts have devised strategies to address the post-colonial politics in their everyday gender expertise work.

Our interviews highlight a hierarchisation of gender issues that follows colonial boundaries between countries and regions. Thus, for example, a gender expert working with the World Bank states:

There are different gender issues. So if you're working in Africa you're focusing on the very basic as we call the first generation issues, you're still battling with girls going to school, with issues such as genital mutilation or HIVIAIDS, maternal mortality which are very primary. ... Here in ... Europe and Central Asia, our problems are a little bit more complex. I mean, in our group we have countries that don't particularly want to believe that they have gender inequality. ... So basically at this point I design new childcare models to target job seekers, or come up with new labour market policies to activate educated women. It's a lot more nuanced. (Interview World Bank, Washington, 2015)

In this quote gender issues are placed on a scale ranging between more "basic", "primary" or "first generation issues", and more "nuanced" or "complex" issues. This hierarchisation follows models of imagined stages of development that inform the core knowledge of development economics, which have long been critiqued for their racialised underpinnings. It places the authority to identify relevant and complex gender issues in the hands of gender experts located in big international institutions, such as the World Bank. Moreover, it arranges "gender issues" from the perspective of a global gaze from World Bank headquarters, whereby the gender expert inhabits the "Archimedean point" or the "point zero", i.e. the role of the objective outside observer (Castro-Gómez, 2005). The problems then no longer are issues of a country or 
individuals, they are now owned by the expert and it is their expert knowledge, drawn from experiences of countries around the world that allows them to devise the proper solutions. This geographical hierarchisation of gender knowledge privileges supposedly universal insights and problem-solving skills over socio-culturally specific gender knowledge and solutions emerging from a particular context.

These practices of hierarchisation and boundary drawing to close off conversations go hand in hand with patronising and colonising attitudes similar to those that have been documented in the field of international development (Hertzog 2011; Kothari, 2005). The 2012 World Development Report (WDR) provides a good example. In the words of one expert, "the only thing that the WDR did was to put the evidence on the table, to just try to settle the discussion" (Interview World Bank, Washington, 2015). The purpose was to establish authoritative truths rather than opening up conversations, e.g. about what are the (important) issues regarding gender, about how they should be addressed and by whom.

The post-colonial embeddedness of gender politics also influences the relationships between experts located in headquarters in the North and those working in particular country contexts. These relationships are characterized by logics of coloniality epitomized in the figure of the "global gender expert". This figure presumes that knowledge about gender is universal and can be applied in any given context. Thus, international gender experts are often sent on missions without any knowledge of the local context (Hertzog, 2011). In the words of one of our respondents: "Look, when you deploy as a Political Affairs or a Security Officer, you are going to get proper training before like briefing on political issues, security issues. As a gender adviser you don't have any briefing" (Interview UN Secretariat, Geneva, 2012). A Nepali gender expert working with a Dalit women's NGO challenged the assumption that gender knowledge is universal, pleading for context-specific gender expertise: 
We should have to develop ourselves as a gender expert in the country's contents. Even the global gender expert should ... know the women's problems within a country. It's not possible to be a global expert, you cannot have all the country knowledge on the women, but at least the basics. Like for example in South Asia, we have a caste system. (Interview Dalit women's NGO, Kathmandu, 2015)

The hierarchy of forms of knowledge and the figure of the global gender expert are linked to a key feature that structures the transnational field of gender expertise and draws boundaries between who is considered an expert and who is not: the access to (international) training on gender issues, which is often perceived as a form of symbolic capital within the field. Thus our survey finds that many gender experts working in international governance have been trained in universities in the North and inspired by British scholars. For example, most Liberian gender experts we interviewed have been trained abroad or by foreign gender experts working in Liberia. This in turn influences what is considered as legitimate gender expertise and who is considered a gender expert. As a Liberian individual working on gender issues stated when asked whether she would call herself a gender expert:

No, we are not gender experts, YOU are a gender expert. You live in Geneva, where people talk about gender, where everybody knows about gender. We are trying to be gender experts. But we don't have sufficient training yet, we only had three trainings at the police academy and the training of trainers by UNMIL (UN Mission in Liberia). ... We would like to have more training from the internationals. (Interview Liberian National Police, Monrovia, 2013)

Establishing itself as a universally valid and authoritative form of expertise, gender expertise can easily become complicit in logics of coloniality that invisibilise other forms of knowledge about gender. The figure of the global gender expert erases boundaries in order to establish gender expertise as a legitimate form of universal knowledge, which 
creates more space for gender expertise to be heard in relation to other forms of expertise within an institution or a mission, such as UNMIL. Yet, at the same time, it established new boundaries whereby the type of training and origin shape the legitimacy of gender knowledge.

Yet, the boundary-erasing practices of gender experts also create situations whereby the association with gender experts from abroad might be damaging to certain women's struggles. Thus, for example, still in the Liberian context, being associated with foreign gender experts and having done trainings sometimes de-credibilises work on women's or gender issues. Some of our respondents voiced concerns over "local" gender experts "just doing it for the money" or "collaborating with those who intervene" (Interview international organisation, Monrovia, 2013). Some gender experts deal with this issue by reflexively recognizing the boundary. Thus, one of our respondents who works in the field of gender and the security sector, underscored the need for local participation as a way to address hierarchies and to move beyond the notion of universal gender expertise:

As gender conceptualizations are completely linked to culture, understandings of men and women's gender roles are completely different, and I think that's why having a participatory approach where you ask "what are gender roles here for you?" is really important. ... Some things maybe don't change, like needing to have some form of a needs assessment ... but that also has to do with us being externals who don't understand the situation. (Interview Centre for the Democratic Control of Armed Forces, Geneva, 2014)

This quote also shows a general openness regarding the socio-culturally specific understandings of gender issues and regarding the "need to learn" for externals. Such an attitude can go a long way to address the issues linked to post-colonial politics. 
Indeed, many of our respondents working as gender experts for local NGOs or civil society organisations in Liberia and Nepal called for dialogue, exchange of information and experience, and circulation of knowledge on gender (Kunz 2016). In Liberia, this process played out between "international" experts working with IOs and INGOs to bring knowledge and training to Liberia and to implement programmes designed in headquarters on the one hand, and Liberian gender experts pushing for an exchange of information and dialogue on the other. For example, when we interviewed the gender team at the Liberia National Police - which has undergone various trainings by foreign gender experts as part of the gender mainstreaming programme of UNMIL's postconflict intervention - they expressed that they enjoyed gender trainings because they gave them the opportunity for exchange of experiences and mutual learning. They recalled international gender trainings where participants shared the particular forms of gendered socialisation and gender discrimination they experienced in their respective countries and cultures. During our interviews, they asked us about gender relations and women's rights in Switzerland (e.g. how many women police do you have in Switzerland?), using the interview setting as an opportunity for an exchange of information. Some gender experts at $1 \mathrm{O}$ headquarters also questioned hierarchies and closure. One security sector gender expert based in New York remarked: "I think anytime you use the word expert, you're sort of marking a certain level of authority with that ... but of course as a feminist, one might also question our ability to have that level of knowledge" (Interview Geneva Centre for the Democratic Control of the Armed Forces, 2014).

Thus, the transnational field of gender expertise is shaped by logics of coloniality and coloniality shapes the constitution of expertise more broadly. Boundary-drawing practices within this field follow colonial logics in determining who knows and what constitutes authoritative knowledge on gender issues. Yet, recognising these colonial logics in boundary-negotating also challenges the claims about gender expertise being technical and shows that the field is intensely political. It represents a site where postcolonial politics are continuously negotiated and addressed through everyday gender expertise work. 


\section{Conclusion}

In this article we have argued for a new theorisation of gender expertise as a transnational social field whose contours are best understood by examining contestations over the boundaries that define it. In doing so, we shift the focus from studying femocrats or feminist insiders to studying an intellectual space. And rather than thinking of this space as devoid of politics (as assumed in much of the mainstream IR literature on expertise) or depoliticizing (as often claimed by feminists), we approach it as highly political, riven by divisions and arguments. Indeed, we argue that contestations over its boundaries performatively establish the field. This way of theorising gender expertise allows us to make a double contribution to the existing literature: we highlight that gender expertise is not just technical knowledge but intensely political, and we show that feminisms cannot be reduced to movement activism, but live inside expertise and are part of the contestations within this transnational field.

Our research leads us to suggest three axes of contestation derived from the embeddedness of the field in feminist and post-colonial politics. These shape the various boundary drawing, erasing and negotiating practices within the field. First, we find that the field is battling and bustling with the spirit of feminism, which some declare as irrelevant, extreme and unhelpful, while others consider central to gender expertise. Second, many experts seek to counteract the fragility of gender expertise by erasing its boundaries to positivist sciences while others fear that this may lead them to lose sight of the "real issue". Finally, the field is embedded in coloniality logics that shape its boundary-negotiating practices, with contestations centring on the value of different kinds of knowledge and challenges to universalist attitudes.

The overall aim of this article is to sketch a new form of theorising gender expertise, illustrated with examples from our research data. As such, we do not claim to have 
exhaustively chronicled the range of cleavages that structure the field and consider our article a starting point for further analysis. For example, other axes of differentiation that have emerged in discussions in our project involve disciplinary commitments, especially between gender experts trained in law and economics; issue areas, such as development and security where gender experts might deploy different logics; and different language communities that draw on different intellectual sources for inspiration. Examinations of these differences can provide further insight into the contested boundaries of gender expertise.

Beyond raising new questions, we hope to inspire the practice of gender expertise. As feminist academics we are particularly concerned about the marginal role of women's and gender studies for the work of gender experts in certain contexts. Insights from gender studies and feminist theory can provide guidance for individuals working on gender issues when navigating the various boundaries and points of contestation of the field. For example, feminist theorizing and methodologies have much to offer for not only seeing but also engaging with post-colonial politics in productive ways. Moreover, feminist methodologies give guidance on how to create knowledge once the project of knowledge creation is revealed as utterly political. In this context, we find worrisome the attraction of positivist logics for gender experts eager to make the business case for gender equality, drawing numerous boundaries. Gender studies, thanks to deep sensibilities for intersectionality, coloniality, and situated knowledges, provide ample resources for the development of expertise that is profoundly political and practical at the same time.

Our analysis pushes us to question the very notions of expertise and experts as they have been conceived of in the literature. Gender expertise takes many forms. Whereas in some contexts it might involve designing and implementing technical solutions, or producing data to support the business case for gender equality, many gender experts also practice deconstructing, analysing, and assessing, reinventing what the role of an expert should be and what expert knowledge means. As we have seen, some individuals working on gender challenge the implementation of ready-made gender 
equality projects and call for dialogue, exchange of information and mutual learning. Thus, the various cleavages that structure the field of gender expertise also open space for new forms of relations and for practicing critical self-reflection. They provide an opportunity to re-remember and re-create feminisms by reclaiming the term, recognizing its multiple origins and manifestations and challenging univocal accounts of a trajectory of co-optation through gender expertise. 


\section{Works Cited}

Abbott, A. (1988) The System of Professions: An Essay on the Division of Expert Labor. University of Chicago Press.

Adler-Nissen, R. (2014) Opting out of the European Union: diplomacy, sovereignty and European integration. Cambridge: Cambridge University Press.

Best, J. (2014) Governing failure: provisional expertise and the transformation of global development finance. Cambridge ; New York: Cambridge University Press.

Boswell, C. (2008) 'The political functions of expert knowledge: knowledge and legitimation in European Union immigration policy', Journal of European Public Policy, 15(4), pp. 471-488. doi: 10.1080/13501760801996634.

Bourdieu, P. (1988) Homo Academicus. Stanford University Press.

Bourdieu, P. (1999) 'The specificity of the scientific field', The science Studies Reader. Ed. Biagioli M. New York: Routledge, pp. 31-50.

Bustelo, M., L. Ferguson, and M. Forest, eds. (2016) The Politics of Feminist Knowledge Transfer: Gender Training and Gender Expertise. Houndmills, Basingstoke, Hampshire: Palgrave Macmillan.

Brunila, K. (2013) 'Persuasions, Resistance and Other Discourse Virtuosities: The Ambivalent Position of the Equality Specialist'. GENEROS - Multidisciplinary Journal of Gender Studies, no. 1 (25 February): 81-102.

Castro-Gómez, S. (2005) La hybris del punto cero: ciencia, raza e ilustración en la Nueva Granada (1750-1816). Bogota: Pontificia Universidad Javeriana.

Chatterjee, P. (1989) 'Colonialism, nationalism, and colonialized women: The contest in India', American ethnologist, 16(4), pp. 622-633.

Dezalay, Y. and Garth, B. G. (2011) 'Hegemonic Battles, Professional Rivalries, and the International Division of Labor in the Market for the Import and Export of StateGoverning Expertise', International Political Sociology, 5(3), pp. 276-293. doi: 10.1111/j.1749-5687.2011.00134.x.

Eyal, G. and Buchholz, L. (2010a) 'From the Sociology of Intellectuals to the Sociology of Interventions', Annual Review of Sociology, 36(1), pp. 117-137. doi: 10.1146/annurev.soc.012809.102625.

Eyal, G. and Buchholz, L. (2010b) 'From the Sociology of Intellectuals to the Sociology of Interventions', Annual Review of Sociology, 36(1), pp. 117-137. doi: 10.1146/annurev.soc.012809.102625.

Eyben, R. and Turquet, L. (eds) (2013) Feminists in Development Organizations: Change from the Margins. Bourton on Dunsmore: Practical Action. Available at: 
http://www.ids.ac.uk/publication/feminists-in-development-organizations-change-fromthe-margins (Accessed: 5 February 2015).

Faulconbridge, J.R. and D. Muzio. (2012) 'Professions in a Globalizing World: Towards a Transnational Sociology of the Professions'. International Sociology 27, no. 1 (January): 136-52.

Ferguson, L. (2015) “This Is Our Gender Person"'. International Feminist Journal of Politics 17, no. 3 (3 July): 380-97.

Griffin, P. (2009) Gendering the World Bank: Neoliberalism and the Gendered Foundations of Global Governance. Houndmills, Basingstoke, Hampshire: Palgrave Macmillan.

Haas, P. M. (1992) 'Epistemic Communities and International Policy Coordination', International Organization, 46(1), pp. 1-35.

Haas, P. M. and Haas, E. B. (2002) 'Pragmatic constructivism and the study of international institutions', Millennium-Journal of International Studies, 31(3), pp. 573601.

Hertzog, E. (2011) Patrons of Women: Literacy Projects and Gender Development in Rural Nepal. Berghahn Books.

Icaza, R. (2017) 'Decolonial Feminism and Global Politics: Border Thinking and Vulnerabilit as a Knowing Otherwise', in Woons, M. and Weier, S. (eds) Critical epistemologies of global politics. Bristol: E-International Relations, pp. 26-48. Available at: http://www.e-ir.info/wp-content/uploads/2017/06/Critical-Epistemologies-of-GlobalPolitics-E-IR.pdf.

Kothari, U. (2005) 'Authority and expertise: The professionalisation of international development and the ordering of dissent', Antipode, 37(3), pp. 425-446.

Kunz, R. (2016) 'Windows of Opportunity, Trojan Horses, and Waves of Women on the Move: De-colonizung the Circulation of Feminist Knowledges through Metaphors?', in Bustelo, M., Ferguson, L., and Forest, M. (eds) The Politics of Feminis Knowledge Transfer: Exploring Gender Training and Gender Mainstreaming. London: Palgrave, pp. 99-117.

Kunz, R. (2017) 'Beyond depoliticisation: the multiple politics of gender expertise', in Verschuur, C. (ed.) Expertes en genre et connaissances féministes sur le développement: Qui sait ? Paris: Editions L'Harmattan, pp. 73-87.

Leander, A. (2010) 'Habitus and Field', International Studies Compendium Project, edited by $R$. Denemark. Oxford: Blackwell Reference Online. Available at: http://openarchive.cbs.dk/handle/10398/7966 (Accessed: 2 October 2012).

Littoz-Monnet, A. (2017) The Politics of Expertise in International Organizations: How International Bureaucracies Produce and Mobilize Knowledge. Routledge. 
Lugones, M. (2008) 'Coloniality and Gender', Tabula rasa, (9), pp. 73-102.

Muzio, D., D.M. Brock, and R. Suddaby. (2013) 'Professions and Institutional Change:

Towards an Institutionalist Sociology of the Professions'. Journal of Management Studies 50, no. 5: 699-721.

Prügl, E. (2016) 'Neoliberalism with a Feminist Face: Crafting a New Hegemony at the World Bank', Feminist Economics, 23(1), pp. 30-53.

Ross, F.J. (2018) 'Professional Feminists: Challenging Local Government inside Out'. Gender, Work \& Organization 0, no. 0 (2018).

Sending, O. J. (2015) The Politics of Expertise: Competing for Authority in Global Governance. University of Michigan Press.

Shepherd, L. J. (2017) Gender, UN Peacebuilding, and the Politics of Space: Locating Legitimacy. Oxford University Press.

Sinha, M. (1995) Colonial Masculinity: The 'manly Englishman' and The' Effeminate Bengali' in the Late Nineteenth Century. Manchester University Press.

Spivak, G. C. (1985) 'Three women's texts and a critique of imperialism', Critical Inquiry, 12(1), pp. 243-261.

Thompson, H. and Prügl, E. (2015) 'Gender Experts and Gender Expertise: Results of a Survey', PGGC Working Paper, No. 8.

Towns, A. (2009) 'The status of women as a standard of "civilization"', European Journal of International Relations, 15(4), pp. 681-706. 